Muchamad Imam Bintoro ${ }^{1}$

1Prodi $M$ anajemen, Fakultas E konomi dan Bisnis, Program Studi M anajemen, U niversitas M uhammadiyah Yogyakarta Jalan B rawijaya, Tamantirto, K asihan, Bantul, Yogyakarta 55183

1E mail: bintoro_ku@yahoo.com

\section{Pemberdayaan UMKM Berbasis Penilaian Agunan Sebagai Upaya Peningkatan Akses Ke Perbankan}

https:/ / doi.org/ 10.18196/ bdr.5223

\begin{abstract}
ABSTRAK
Usaha Mikro, Kecil, dan Menengah (UMKM) di Indonesia menunjukkan perkembangan yang menggembirakan. Perkembangan ini tentu saja tidak terlepas dari peran perbankan. Akan tetapi, permasalahan yang sering muncul adalah banyaknya permohonan kredit dari UMKM yang ditolak bank karena alasan kecukupan nilai agunan. Bergerak dari permasalah ini maka perlu dilakukan kegiatan untuk memberikan pengetahuan baik teori maupun praktek terkait dengan penilaian agunan bagi UMKM. Kegiatan pemberdayaan UMKM ini dilaksanakan berkat kerjasama yang baik dengan praktisi penilai agunan (appraisal) dari Kantor Jasa Penilai Publik dan Pusat Pengembangan Manajemen FE UMY. Pelibatan pihak appraisal dipandang penting karena pada prakteknya profesi inilah yang diberikan otoritas oleh bank untuk menentukan nilai dari agunan calon debiturnya. Kerjasama dengan PPM FE UMY dilakukan karena lembaga ini mempunyai telah mempunyai mitra binaan UMKM di Daerah Istimewa Yogyakarta.
\end{abstract}

Kata Kunci : UMKM, bank, kredit, nilai

\title{
PENDAHULUAN
}

U saha Mikro, Kecil, dan Menengah (U M KM) di Indonesia menunjukkan perkembangan yang menggembirakan. Berdasarkan data yang dihimpun dari kementrian koperasi dan U M KM jumlah U M KM di Indonesia telah berkembang dari 52.764 .750 unit pada tahun 2009 telah berkembang menjadi 59.000.000 unit pada tahun 2017. Perkembangan U MKM yang pesat tentu saja tidak terlepas dari peran perbankan di Indonesia. M enurut U ndang-U ndang (U U ) Pokok Perbankan N o.10 tahun 1998 Bab I Ps. 1 ayat (2) menyebutkan bahwa Bank adalah badan usaha yang berperan menghimpun dana dari masyarakat dalam bentuk simpanan, dan menyalurkan nya kepada masyarakat dalam rangka meningkatkan taraf hidup rakyat banyak. Dari definisi di atas jelaslah bahwa salah satu peran utama dari bank adalah meningkatkan taraf masyarakat dengan 
cara memberikan kredit kepada masyarakat, pada umumnya dan sektor usaha, pada khususnya.

Untuk meminimalkan risiko pemberian kredit kepada masyarakat maka bank mensyaratkan penyerahan agunan dari debiturnya. M enurut U U No 10 tahun 1998 Ps.1 ayat (23) disebutkan bahwa agunan adalah jaminan tambahan yang diserahkan nasabah debitur kepada bank dalam rangka pemberian fasilitaskredit atau pembiayaan berdasarkan Prinsip Syariah. Salah satu permasalahan yang muncul dalam pengembangan bisnis U M KM pada saat ini adalah pada nilai aset U M KM yangakan digunakan sebagai agunan bank. Pihak bank terkadang secara sepihak menolak permohonan kredit dari U M KM dengan alasan agunannya tidak mencukupi untuk menutup kredit yang diajukan. Lebih lanjut, pihak perbankan terkadang tidak memberikan penjelasan secara gamblang mengapa nilai agunan tersebut tidak cukup dan bagaimana menentukan nilai dari agunan tersebut.

Penentuan nilai pasar properti dilakukan dengan 3 (tiga) pendekatan penilaian yaitu Pendekatan pasar, pendekatan pendapatan dan pendekatan biaya. Pendekatan data pasar (market data approach) adalah pendekatan yang mempertimbangkan penjualan dari properti sejenis atau pengganti dan data pasar terkait, serta menghasilkan estimasi nilai melalui prosesperban dingan. Pada umumnya, properti yang dinilai (objek penilaian) dibandingkan dengan transaksi properti yang sebanding, baik yang telah terjadi maupun yang masih dalam tahap penawaran penjualan dari suatu proses jual beli (SPI, 2015). D alam pendekatan data pasar dilakukan proses penyesuaain (adjustment) antara properti yang dinilai dengan data-data pembanding. Terdapat dua metode penyesuaian yang dapat digunakan yaitu metode kuantitatif dan metode kualitatif, yang digunakan salah satu atau keduanya sekaligus. Penyesuaian kuantitatif diturunkan dalam analisis penyesuaian dan diaplikasikan dalam bentuk jumlah numerik. M etode kualitatif dijelaskan dalam istilah yang menyampaikan besarnya perbedaan properti subjek dan properti sebanding dalam masing-masing elemen perbandingannya (Apparisal Institute, 2008). Prawoto (2015, hal 388-389) mengatakan bahwa penyesuaian kuantitatif dikembangkan menurut nilai nominal rupiah atau presentasinya. Sedangkan sebaliknya penyesuaian secara kulaitatif digunakan untuk faktor yang tidak bisa dikuantitatifkan.

Pendekatan biaya adalah pendekatan yang mempertimbangkan kemungkinan bahwa, sebagai substitusi dari pembelian suatu properti, seseorang dapat membuat properti yang lain baik berupa replika dari properti asli atau substitusinya yang memberikan kegunaan yang sebanding. Dalam prakteknya, pen dekatan ini juga melibatkan estimasi depresiasi 
untuk properti yanglebih tua dan/ atau memiliki keusangan dimana estimasi biaya baru secara tidak wajar melampaui harga yang mungkin dibayarkan untuk properti yang dinilai (SPI, 2015). Pendekatan pendapatan adalah pendekatan yang mempertimbangkan pendapatan dan biaya yang berhubungan dengan properti yang dinilai dan mengestimasikan nilai melalui proses kapitalisasi. Kapitalisasi menghubungkan pendapatan (biasanya merupakan pendapatan bersih) dengan suatu definisi jenis nilai melalui konversi pendapatan menjadi estimasi nilai. Proses ini mungkin menggunakan kapitalisasi langsung (dikenal dengan tingkat kapitalisasi), yield atau tingkat diskonto (menggambarkan tingkat pengembalian investasi), atau keduanya. Pada umumnya prinsip subsitusi mengandung pengertian bahwa arus pendapatan yang menghasilkan tingkat pengembalian tertinggi adalah sebanding den gan tingkat risiko yang diambil dan akan menghasilkan nilai yang paling mungkin terjadi (SPI, 2015).

Berdasarkan masalah diatas, maka rendahnya pengetahuan U M KM dalam penilaian agunan mereka inilah yang mendorong dilakukannya pengabdian masyarakat ini sebagai upaya meningkatkan bankabilitas U MKM . Luaran program pengabdian masyarakat melalui publikasi ilmiah Berdikari: Jurnal Inovasi dan Penerapan Ipteks.

\section{METODE PELAKSANAAN}

M etode pelaksan aan pengabdian masyarakat ini tersaji dalam gambar 1 di bawah ini.

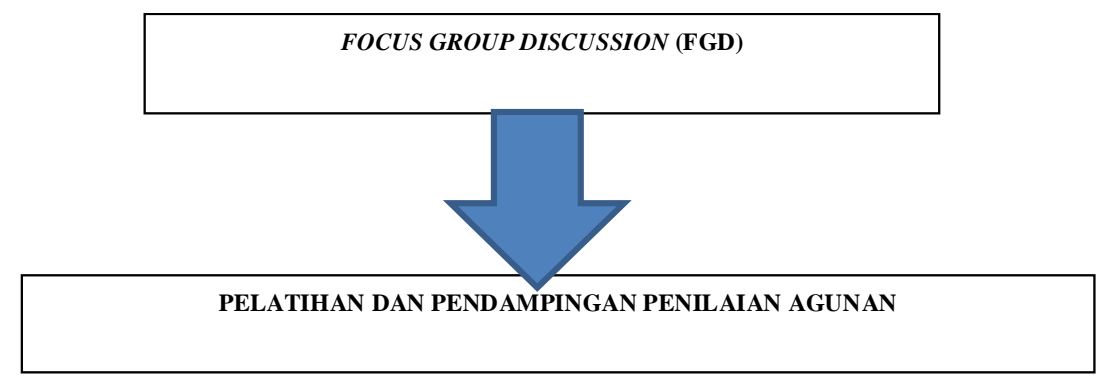

Gambar 1. Metode pelaksanaan

Pemberdayaan U M KM berbasis penilaian agunan dilakukan dengan tahapan kegiatan sebagai berikut:

a. Focus group discussion (FGD) dengan pihak yang berkompeten dalam hal penilaian agunan yang dalam hal ini adalah kantor jasa penilai publik. Secara teoritis Focus Group Discussion (FGD) didefinisikan sebagai teknik pengumpulan data kualitatif yang didesain untuk memperoleh informasi keinginan, kebutuhan, sudut pandang, kepercayaan dan pengalaman peserta tentang suatu topik, dengan pengarahan dari seorang fasilitator atau moderator (Astridya Paramita dan Lusi Kristiana (2015). Tujuan 


\section{3}

dari FGD pada pen gabdian masyarakat ini adalah untuk mendapatkan pengetahuan mengenai metode yang digunakan para penilai aset dalam melakukan tugasnya menentukan nilai agunan calon debitur bank. Perlu diketahui bahwa bank mempercayakan penilaian agunan calon debiturnya berdasarkan opini nilai yang dikeluarkan oleh penilai aset (appraisal). Besaran nilai dalam bentuk opini penilai inilah yang menjadi dasar bagi bank untuk memberikan berapa besar kredit yang diberikan kepada calon debiturnya. Pelibatan kantor jasa penilai publik diharapkan mampu memberikan pemahaman penilaiaan agunan yang tepat, sehingga dapat membantu U M KM dalam menentukan nilai dari agunan yangakan diberikan kepada bank sebagai jaminan kredit mereka.

b. Kegiatan pelatihan dan pendampingan kepada pelaku U M KM mengenai metode penilaian agunan yang tepat untuk kepentingan penjaminan kredit bank. Kegiatan ini dilakukan bekerjasama dengan Pusat Pengembangan M anajemen (PPM ) FE U M Y. Pelibatan PPM FE UMY ini dilakukan dikarenakan PPM adalah lembaga yang mempunyai mitra binaan U M KM dan mempunyai komitmen untuk selalu memajukan U M KM di wilayah DIY. Kegiatan pelatihan dan pendampingan ini pada prinsipnya ditekankan peningkatan pemahaman U M KM pada dua jenis agunan yang sering disyaratkan oleh pihak bank yaitu tanah dan bangunan, walaupun pada prinsipnya, masih banyak jenis agunan lain yang juga dapat digunakan sebagai agunan, sebagai contohnya adalah persediaan barang, mesin dan peralatan dan lain-tain. Kegiatan pelatihan dan pendampingan mengenai penilaian agunan selain tanah dan bangunan dapat dijadikan rekomendasi untuk kegiatan pengabdian masyarakat berikutnya.

\section{HASIL DAN PEMBAHASAN}

$\mathrm{H}$ asil pengabdian masyarakat ini dimulai dengan melakukan $\mathrm{FGD}$ dengan Kantor Jasa Penilai Publik (KJPP) N anang R ahayu dan Rekan yang bertempat di perum M unggur I nomor 4, Jalan Godean km 7,5, Sleman, Daerah Istimewa Yogyakarta. Pada FG D ini dimulai dengan pemaparan dari pihak KJPP mengenai beberapa hal-hal antara lain:

a. D efinisi nilai, penilaian dan nilai pasar.

b. Pendekatan-pendekatan yang digunakan dalam penilaian agunan.

c. M etode penilaian agunan dalam bentuk tanah.

d. M etode penilaian agunan dalam bentuk bangunan .

e. Permasalahan-permasalahan yang terkait agunan yang biasa ditemui di dunia praktek perbankan. 
Pihak KJPP juga memberikan apresiasi atas kegiatan ini karena akan memberikan manfaat yang bagus kepada U M KM dalam hal peningkatan bankabilitasnya pada dunia perbankan. Pihak KJPP juga bersedia untuk dilibatkan dalam kegiatan serupa di waktu yang akan datang.

Kegiatan pemberdayaan U M KM berbasis penilaian agunan dilakukan berkerjasama dengan PPM FE U M Y. Kerjasama ini dilakukan karena PPM FE U M Y telah mempunyai mitra binaan U M KM di daerah DIY. U M KM mitra binaan PPM ini secara terus-menerus dilakukan pendampingan dan pemberdayaan sesuai dengan program pen guatan U M KM yang ditetapkan pada periode tersebut. Pada kegiatan ini mitra binaan PPM yang diundang adalah U M KM -U M K M yangtergabung dalam wadah organisasi W anita Islam Yogyakarta.

Pelaksanaan kegiatan pemberdayaan UMKM ini terbagi menjadi dua sesi yaitu pemaparan materi, simulasi dan umpan balik (feedback). Sesi pemaparan materi dilakukan dengan memberikan penjelasan materi-materi yang terkait dengan penilaan agunan sebagai hasil dari FGD dengan KJPP. Pada sesi ini pemaparan dilakukan secara interaktif karena disampaikan tidak melulu secara teoritis tetapi juga aspek praktis sehingga mudah dipahami oleh para peserta. M ateri-materi pokok yang dibahas pada sesi ini, antara lain:

Beberapa pertanyaan penting yang muncul pada sesi ini antara lain:

a. Bagaimana menentukan nilai tanah yang tidak mempunyai akses jalan.

b. Bagaimana menentukan nilai tanah yang berdekatan dengan faktor-faktor negarif seperti kuburan, sutet, tempat pembuangan sampah.

Beberapa aktvitas dalam sesi pertama tercermin dalam gambar 2 dibawah ini:

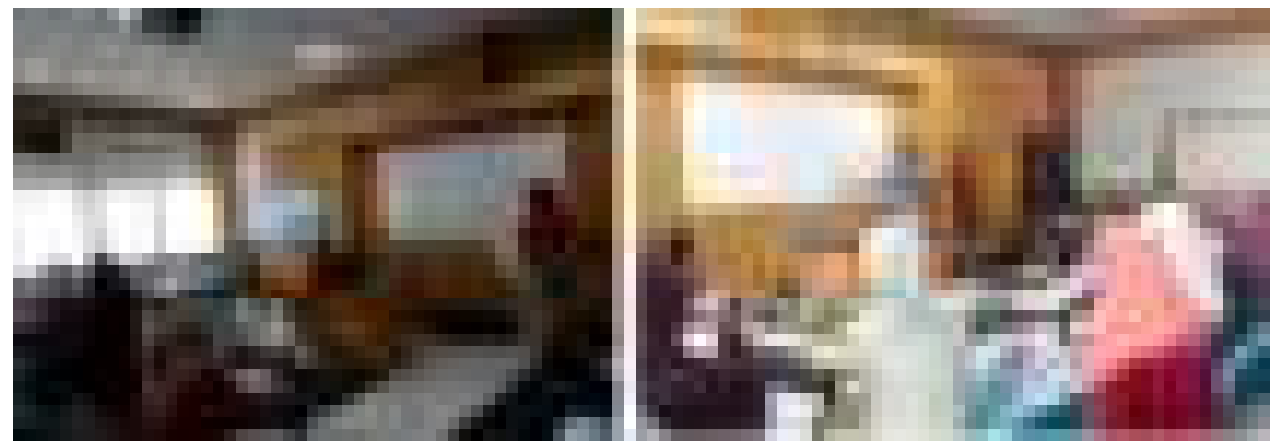

Gambar 2. Aktivitas sesi pemaparan

Sesi simulasi merupakan sesi yang diminati oleh para peserta karena peserta diberikan penugasan untuk menilai tanah dan bangunan yang sudah disiapkan oleh pemateri dalam bentuk kelompok. M asing-masing kelompok diberikan kasus penilaian yang berbedabeda dan dipresentasikan di depan kelompok yang lain. Tujuan yang diharapkan dari prosesini adalah terjadinya pemindahan pengetahuan (transfer knowledge) antar peserta 


\section{5}

dengan pemahaman yang lebih baik kepada peserta yang masih kurang pemahaman terhadap materi pada sesi pertama. Pada sesi ini aktivitas yang terjadi antara lain:

a. Pembahasan kelompok tentang penilaian tanah.

b. Pembahasan kelompok tentang penilaian bangunan.

c. Presentasi hasil masing-masing kelompok.

d. Diskusi dan pembahasan hasil kelompok oleh narasumber.

Kegiatan pemberdayaan U M KM ini diakhiri dengan feedback dari peserta terkait dengan pelaksanan kegiatan. Pada sesi ini muncul beberapa hal yang bisa dicatat antara lain:

a. Peserta secara umum menilai bahwa kegiatan yang diadakan telah memberikan manfaat kepada mereka berupa tambahan pengetahuan baik teori maupun praktek mengenai bagaimana menilai agunan yang akan dijaminkan ke perbankan.

b. Peserta men gharapkan adanya keberlanjutan kegiatan tidak hanya membahas mengenai penilaian tanah dan bangunan saja akan tetapi juga berlanjut untuk membahas mengenai penilaian yang non tanah bangunan, seperti persediaan, kios, los pasar, dan lain sebagainya. Peserta berpen dapat bahwa pada prakteknya jenisjenis non tanah bangunan inilah yang lebih banyak mereka miliki.

Beberapa aktvitas dalam sesi kedua dan ketiga tercermin dalam gambar 3 dibawah ini:
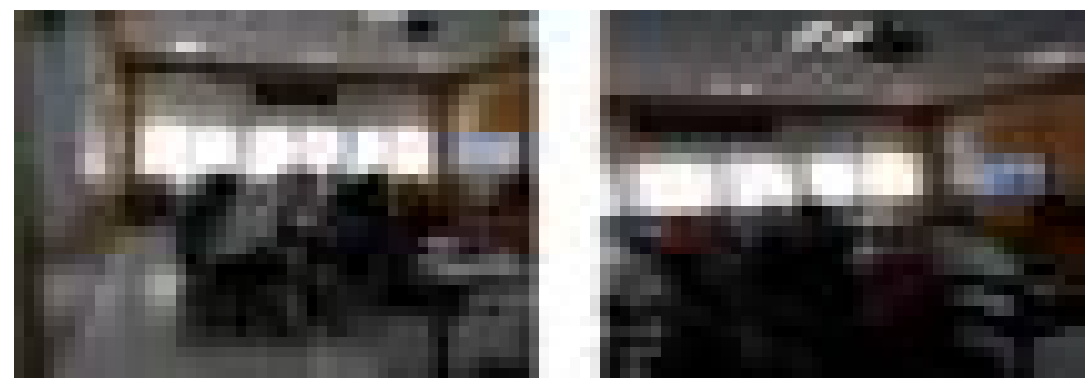

Gambar 3. Aktivitas sesi 2 dan 3

\section{SIM PULAN}

Kegiatan pemberdayaan U M KM berbasis penilaian agunan dapat berjalan lancar terbukti dengan antusiasme peserta dalam mengikuti semua sesi acara. Dalam pemberdayaan ini peserta lebih memahami metode penilaian untuk keperluan penjaminan kredit mereka di bank. Dengan semakin dipahaminya metode untuk menentukan nilai agunan ini diharapkan U M KM dapat semakin maju dan berkembang karena peluang untuk mendapatkan tambahan dana dari bank semakin besar. 
Dari kegiatan pemberdayaan U M KM diajukan beberapa saran sebagai berikut:

1. M asih perlu ditambahkan lagi pemberdayaan masyarakat serupa di waktu yang akan datang.

2. Masih perlu ditingkatkan lagi pemahaman peserta mengenai penilaian agunan melalui program pemberdayaan masyarakat di waktu yang akan datang.

3. Perlunya keterlibatan langsung dari KJPP untuk memberikan wawasan penilaian agunan di dunia praktis.

\section{UCAPAN TERIMA KASIH}

Pada kesempatan ini ucapan terima kasih kami tujukan kepada:

1. Manajemen KJPP N anang Rahayu cabang Yogyakarta

2. Pusat Pengembangan M anajemen Fakultas Ekonomi U MY

3. Wanita Islam D aerah Istimewa Yogyakarta

\section{DAFTAR PUSTAKA}

Agus, Prawoto, 2003, Teori dan Praktek Penilaian Properti, BPFE, Yogyakarta

Appraisal Institut, 2001, The Appraisal of Real Estate, Twelfth, Edition, United States of America

Harjanto, Budi, dan R.,Rianto Edi. 1999, Analisa LPM Terhadap Pengaruh Faktor Lokasi aksesibilitas dalam mempengaruhi nilai tanah, Jurnal Survai dan Penilaian Properti, Vol.014, p. 31-39.

Hidayati, Wahyu dan Harijanto, Budi, 2003, Konsep Dasar Penilaian Properti,BPFE Yogyakarta

Standar Penilaian Indonesia (SPI), 2015, Masyarakat Profesi Penilai Indonesia, Jakarta

Sugianto, 2004, Faktor-Faktor yang Mempengaruhi Harga Tanah di Sekitar Tempat Pembuangan Akhir Sampah Sitimulyo Kabupaten Bantul, Jurnal Survey \& Penilaian Properti, Vol. 47
Supardi, Untung, Materi kuliah Penilaian Aset dan Properti, MEP UGM, 2015

Sutawijaya, Adrian, 2004, Analisis Faktor-Faktor Yang Mempengaruhi Nilai Tanah Sebagai Dasar Penilaian Nilai J ual Obyek Pajak (NJ OP) PBB di Kota Semarang, Jurnal Ekonomi Pembangunan Vol. 9 No. 1, J uni $2004 \mathrm{Hal}$ : $65-78$

Undang-Undang Pokok Perbankan No. 7 tahun 1992 jo UU No. 10 tahun 1998

http://www.ukmkecil.com/ukm/definisi-ukm http://eddiwahyudi.com/2015/03/31/penilaianobjek-tanah-dan-bangunan-untuk-kepentinganpbb-p2/

https://www.jurnal.id/id/blog/2017/perbedaanumkm-perkembangannya-di-Indonesia 